\title{
DEVELOPMENT OF TRADITIONAL CHILDREN PLAY BASED INSTRUCTIONAL MODEL TO OPTIMIZE DEVELOPMENT OF KINDERGARTENERS' FUNDAMENTAL MOTOR SKILL
}

\author{
Wawan S. Suherman*, Dapan, Guntur, \& Nur Rohmah Muktiani \\ Universitas Negeri Yogyakarta Indonesia \\ *e-mail: wansuherman@uny.ac.id
}

\begin{abstract}
Traditional children play is a suitable physical activity for instructional mean in kindergarten. The research intends to develop Traditional Children Play based instructional model to optimize development of fundamental motor skills of kindergarteners. This research used research and development approach from Borg \& Gall. Research's subjects were traditional children play in DIY, and kindergartens in DIY. Data were collected by interview, observation, and ducoments analysis. Collected data were analyzed in three steps: organized and reducted, displayed, and summarized and verificated. The study was done with following activities: identification of theoretical basis and determination of instructional model design, identification and analysis of traditional children play, and validation of instructional model. After being validated by material experts and teaching experts, the traditional children play based instructional model for optimizing the development of kindergarteners' fundamental motor skills consists of: (1) concepts/theoretical basis, (2) activity stages, (3) social systems, (4) principles of reaction, (5) supporting system, and (6) model impact.
\end{abstract}

Keywords: traditional children play, instructional model, fundamental motor skill, kindergarteners

\section{PENGEMBANGAN MODEL PEMBELAJARAN \\ BERBASIS DOLANAN ANAK TRADIDIONAL UNTUK MENGOPTIMALKAN PERKEMBANGAN KETEREAMPILAN MOTORIK DASAR SISWA TK}

\begin{abstract}
Abstrak: Dolanan anak merupakan aktivitas jasmani yang sangat cocok untuk wahana pembelajaran di Taman kanak-kanak. Penelitian ini bertujuan untuk mengembangkan "Model pembelajaran berbasis Dolanan Anak untuk mengoptimalkan pengembangan kemampuan gerak dasar siswa TK. Penelitian ini menggunakan pendekatan penelitian dan pengembangan dari Borg \& Gall. Subjek penelitian adalah dolanan anak yang ada di DIY dan beberapa TK di DIY. Teknik pengumpulan data menggunakan studi pustaka, observasi, dan wawancara. Data yang dianalisis dengan direduksi, disajikan, serta disimpulkan dan diverifikasi. Penelitian yang dilaksanakan adalah pengidentifikasian landasan teoritis dan penetapan disain model, pengidentifikasian dan pengkajian Dolanan anak, serta validasi Model pembelajaran. Setelah divalidasi oleh ahli materi dan ahli pembelajaran, Model pembelajaran berbasis Dolanan anak untuk mengembangkan kemampuan gerak dasar siswa TK terdiri dari: (1) Konsep/landasan teori, (2) tahapan kegiatan, (3) system sosial, (4) prinsip reaksi, (5) system pendukung, dan (6) dampak model.
\end{abstract}

Kata Kunci: dolanan anak, model pembelajaran, kemampuan gerak dasar, siswa taman kanak-kanak

\section{INTRODUCTION}

Childhood is very important period in human life because experience of development and learning at this time will greatly determine the success of life in the future. Naturally, children experience extraordinary developments at this time. Therefore, this development period is often called Golden Age. Realizing this position, the golden age of children continues to be worked on by parents, community, and government.
One effort to facilitate education provided by parents, community, and government is implementation of kindergarten (TK). Nurturing and development process in kindergarten are designed to provide opportunities for children to experience optimal growth. Therefore, developing the potential of children during this golden age, through kindergarten, has very important and strategic role in the development of all children's potentials (Stodden, Goodway, 
Langendorfer, Roberton, Rudisill, Garcia, \& Garcia, 2008; Brubaker, 2011).

One aspect of children's growth and development that needs to be considered and developed in balanced manner is fundamental motor skill(FMS). This is important because FMS is the foundation for the growth of other aspects of development. Haywood \& Getchell (2005) state that in the early childhood years, children begin to learn a group of motor skill known as Fundamental Motor Skill (FMS). Fundamental Motor Skills are composed of locomotor skill, nonlocomotor skills and object control skill. Stodden, et. al. (2008) states that experience and mastery of FMS are very important for children because it will affect physical development and subsequent physical activity. In addition to influencing further mobility, mastery of FMS is believed to affect all aspects of a child's development.

Physical activities favored by children and in accordance with the world of children are traditional children play. Many traditional children play are available and still played by children. Therefore, the use of traditional children play to facilitate the development of FMS is feasible. Morrison (2012); Willis \& Hymon-Parker (2010); Sujiono (2009); Moeslichatoen (2004); Dewantara (2009) state that play have important value as learning means for kindergarten students. Playing is an activity that shows how children learn and assimilate new knowledge and abilities with those they already have. Hartley, Frank, \& Goldenson (2000) add that game is not only meaningful to deliver children to understand the world, but game is an activity that brings children to achieve psychological balance in the early days of their lives. Because game has very important meaning for children, the use of game activities is necessity for kindergarten.

One of the strongest proofs of the connection between traditional children play and kindergarten learning is the expression "playing while learning, learning while playing". Mostafavi, Ziaee, Akbari, \& Haji-Hosseini (2013) state that the results of previous studies show that learning programs that use traditional games are effective and practical way to improve physical fitness and basic movement skills of kindergarten students and elementary school students in Iran. The use of traditional children play in learning is shown by the results of the study of Kovacevic \& Opic (2014) which sums up that the use of traditional games in learning provides many benefits for children. Suherman, Nopembri, \& Muktiani (2017) concluded that traditional children play is suitable for facilitating the teaching learning process in kindergarten.

Even though some results of the study strongly proofed that traditional children play is suitable as a mean for teaching learning processes in kindergartens, but the use of traditional children play in developing the basic motor skills of kindergarten students has not been carried out optimally. Observations at several kindergartens in DIY showed that kindergarten teachers had not used children's toys optimally. The teachers reasoned that they were not equipped with the ability to use traditional children plays in teaching learning process. The teacher does not have many traditional children play's collections.

The collection and potential for traditional children play is very abundant in Yogyakarta Special Region, but its still need to be explored, identified and collected. Indeed, various traditional children games can be found and are still played by children. Therefore, studying the use of traditional children games in kindergarten learning to facilitate the development of foundamental movement skill becomes important and necessary to work on. So, the research will have objective to (1) identify the theoretical framework that can be used to design traditional children play-based instructional model, (2) select traditional children plays as a means for developing fundamental motor skills, (3) validate the instructional model.

\section{METHOD}

This research may be categorised as a qualitative research representing a thick description of a research and development approach for an instructional product, following the procedure of $\mathrm{R}$ and $\mathrm{D}$ from Borg \& Gall (1983). For the benefit of developing traditional children play-based instructional model, this research was process for developing and validating educational products. The research aimed to describe an instructional model baseon traditional children play. The research was done by activities, including (1) conducting library study to obtain theoretical framework for designing Traditional children play-based 
instructional model, (2) conducting field study and literature study to obtain potential traditional children play, and assessing traditional children play's compatibility with characteristics of fundamental motor skill, and (3) implementation of model validation that had been prepared by material experts and learning experts.

\section{RESEARCH RESULT AND DISCUSSION}

After performing preliminary study, designing and validating Traditional Children play-based instructional model to facilitate the development of fundamental motor skills of kindergarten students, results of research and discussion are presented as follows.

\section{Result}

This research produced Traditional children play-based instructional model to optimize the development of fundamental motor skills of kindergarten students. Researchers did literature study and field study to get targeted data. The results of the study are presented as follows.

\section{Identification of Theoretical Framework and Instructional Model Designing}

Collected data about theoretical framework on developing fundamental motor skills were presented on Table 1. The basic movement skills develop not only due to age maturation process, but also influenced by environmental factors such as opportunity to practice, encouragement and learning experienced by the child. Thus, the development of basic movement skills needs to be facilitated by learning opportunities and planned learning environment. In order for learning to take place optimally and produce the expected capacity and change, the teacher needs to create enjoyable learning environment and is known by students. Conditioning uses the foundation of Bandura's Cognitive Learning Theory (in Schunk, 2012).

The use of Bandura Cognitive Theory in kindergarten learning is in line with the opinions of Joyce, Weil, \& Calhoun (2009) that teaching model is design and preparation of teaching learning environment so students can interact with material and the environment, learn well, depiction of teacher behavior during the process. Skinner (in Schunk, 2012) suggests that learning can occur effectively, teachers need to (1) present teaching materials in stages with small portions, (2) students actively participate, (3) the teacher gives feedback immediately, and (4) students move teaching materials according to their respective speed. The model proposed by Skinner is called the instructional model.

Eggen \& Kauchak (2012); Joyce, et. al. (2009); Metzler (2011); Suherman, et. al. (2017) state that instructional model is design about process details of interaction activities among students, teachers, materials, and structuring learning environment so that teaching learning processes occur leading to changes towards better development. The components of instructional model consist of (1) theoretical concept/basis, (2) learning structure, (3) social system, (4) reaction principles, (5) support systems, and (6) learning impact. Details of elements of the instructional model are presented in the Table 2.

\section{Identification of Dolanan Anak (Traditional Children Play)}

In order for the teaching-learning process to provide influences and experiences that are interesting, encouraging, and challenging for children, instructional is done by using medium that are well-known to children and containing the elements of movement that will be taught called as traditional children play.

Study on research results by Suherman, et. al. (2017); plus results of observations in fields that have succeeded in collecting various types of traditional children play from 5 districts/city in Yogyakarta Special Region are collected 87 Traditional children plays. The 87 traditional children plays identified, then analysed on which potential plays are used in developing fundamental motor skills, by examining the elements of movement in traditional children play, and the characteristics of fundamental motor skills to be developed. The results are obtained that 23 traditional children plays which can be used to develop fundamental motor skills as follows:

(1) Ambah-ambah lemah, (2) Benthik, (3) Bethet Thing Thong, (4) Blarak-blarak sempal, (5) Boy-boynan, (6) Dhul-dhulan, (7) Engklek/Sunda Manda, (8) Gamparan; (9) Gatheng. (10) Gobak sodor,(11) Ingkling Gunungan, (12) Jamuran, (13) Jeg-jegan, (14) Jethungan/Dhelikan, (15) Jlong-jling kitiran, (16) Kasti, (17) Kotak 
Tabel 1. Theoretical Summary for Developing FMS

\begin{tabular}{|c|c|c|c|}
\hline No & Theory & Description & Reference \\
\hline 1 & Growth and development & $\begin{array}{l}\text { Growth means changes in the quantity experienced by } \\
\text { children, such as height, weight, and body size. } \\
\text { Development means that children experience } \\
\text { qualitative development in various abilities. }\end{array}$ & Morrison (2012) \\
\hline 2 & $\begin{array}{l}\text { Stages of Motor } \\
\text { Learning }\end{array}$ & $\begin{array}{l}\text { Describe about stages of motor learning that consist of } \\
\text { cognitive stage, associative stage, and automatic stage }\end{array}$ & Magill (1993) \\
\hline 3 & Transfer of Learning & $\begin{array}{l}\text { Previous developments and capabilities that have } \\
\text { already earned become the foundation and influencing } \\
\text { future developments. }\end{array}$ & Schunk, (2012) \\
\hline 4 & $\begin{array}{l}\text { Dynamic system and } \\
\text { growth principles; }\end{array}$ & $\begin{array}{l}\text { Development is sustainable and accumulative process, } \\
\text { previous developments and capabilities become the } \\
\text { foundation and influencing future developments, } \\
\text { Motor development progressing gradually, the } \\
\text { maturation of motor system takes place from gross } \\
\text { motor to fine motor, motor development moves from } \\
\text { head to feet, occurs from center of body to outside of } \\
\text { body. }\end{array}$ & Bahtiar (2016) \\
\hline 5 & $\begin{array}{l}\text { Developmentally } \\
\text { Appropriate Practice in } \\
\text { ECP. }\end{array}$ & $\begin{array}{l}\text { Early childhood program should suitable with the } \\
\text { development stage of children }\end{array}$ & $\begin{array}{l}\text { Bredekamp \& } \\
\text { Copple (1997); }\end{array}$ \\
\hline 6 & Constructivism & $\begin{array}{l}\text { Learning is an active, constructive process. The } \\
\text { learner is an information constructor. People } \\
\text { actively construct or create their own subjective } \\
\text { representations of objective reality. }\end{array}$ & $\begin{array}{l}\text { Schunk, (2012); } \\
\text { Morrison (2012). }\end{array}$ \\
\hline 7 & $\begin{array}{l}\text { Bandura Social } \\
\text { Cognitive Learning }\end{array}$ & $\begin{array}{l}\text { People learn by watching what others do, and that } \\
\text { human thought processes } \\
\text { are central to understanding personality. This theory } \\
\text { provides a framework for understanding, predicting } \\
\text { and changing human behavior } \\
\text { Bandura view of triadic reciprocality } \\
\text { and define human behavior as a triadic, dynamic, and } \\
\text { reciprocal interaction of personal factors, behavior, } \\
\text { and the environment. }\end{array}$ & $\begin{array}{l}\text { Schunk, (2012); } \\
\text { Morrison (2012). }\end{array}$ \\
\hline
\end{tabular}

Pos, (18) Kucing-kucingan, (19) Lurahlurahan, (20) Sekong, (21) Sobyung, (22) Tawon-tawonan, and (23) Ular Naga.

The selection of traditional children play as medium in instructional model is based on the implementation of learning theory, adapted to the characteristics and needs of kindergarten students, and harmonized with the characteristics of Kindergarten teaching learning. In addition, traditional children play have values and elements of movement that are relevant with the needs of the development of children fundamental motor skills.

\section{Experts Validation on Instructional Model}

After identifying the theory, applying the model design and reviewing traditional children play, the last activity in the study was expert validation. To get the model that fit the needs of the field, expert validation was done in the form of filled-out a validation's instrument and Focus Group Discussion. The experts invited were (1) Joko Pamungkas, M.Sc. Kindergarten Learning Expert from Early Childhood Education Study Program/PG PAUD FIP UNY Study Program, (2) Sri Mawarti, M.Pd. traditional game expert from FIK UNY, (3) Susanti, M.Pd. from Gunungkidul Regency Kindergarten supervisor.

The three invited experts were validated the instructional model that had been prepared. Assessment was used the instrument of 1 4 rating scale. Indicators of the isntrument are (1) the concept of instructional models, (2) conformity of theoretical foundation and instructional models, (3) completely components of instructional models, (4) accuracy of selection 
Table 2. Traditional Children Play-based Instructional Model

\begin{tabular}{l} 
Traditional Children Play Based-Instructional Model \\
\hline 1. Concept/ Theoretical Basis: \\
Description of concepts or theories used as basis for developing learning models. Traditional Children \\
Play-based Instructional Model is a design or blueprint of the teaching learning process that uses traditional \\
children's play as a means for developing fundamental movement skills. \\
2. Activity Stage \\
Stage of teaching-learning process is the steps or stages of the teaching-learning process that must be \\
implemented by teachers and students. The teaching-learning stage includes the following activities. \\
\begin{tabular}{lll} 
No & Step of Activity & \\
\hline 2.1. & Opening & Opening; Morning meeting (Circle Time); question- answer. \\
2.2. & Main Activity & Family Corner \\
2.3. & Break & Break Prayer; prayers for enter and exit bathroom \\
2.4. & Closing & Afternoon meeting; Evaluation and reflection of today's activity; Closing:
\end{tabular} \\
\hline
\end{tabular}

\section{Social System}

Part of the instructional model that explains roles and relationships between teacher and students in the teaching-learning process.

\section{Reaction Principle}

Reaction principle explains how the teacher responds to student behavior and activities during the teachinglearning process.

\section{Support System}

Support system is part of the instructional model that explains conditions needed to apply the teaching-learning process, such as Lesson Plan, Student Task Sheet, and other learning resources.

\section{Model Impact}

Direct (instructisonal) impact/ planned goals to be achieved and indirect impact (nurturant) / accompaniment impacts caused by learning.

and utilization of traditional children's play, (5) compatibility traditional children play with FMS elements developed. In general, the three experts have agreed that instructional model based traditional children play will be able to develop fundamental motor skills optimally. This is indicated by the acquisition of scores for all points of assessment resulting in an average of 3.08 to 4.00 .

In addition to conducting assessments, the three experts conducted FGDs with 16 kindergarten teachers of Yogyakarta. Experts and participants made several revisions and advices to improve the draft model. Advices from experts and discussion participants were as follows. First, types and values of Traditional children play must be more identified. The selection of 23 traditional children play needed to look at the values and elements of movement found in traditional children play before it was decided that it was suitable to be a vehicle for developing fundamental motor skills. Second, traditional children play were accompanied by poetry or traditional children play songs. In addition, matchmaking and use of traditional children play to teach certain topic/themes needed to be examined more closely by paying attention to the values of traditional children play, the possibility of students being able to do so, the level of students' ability, and the introduction of teachers to ability. Third, the use of traditional children play in teaching-learning process needed to consider children ease in doing so, needed to be varied and mixed, so that children did not experience boredom and were more happy and cheerful during learning.

Regarding and considering suggestions and inputs from experts and FGD participants to the instructional model draft, it seemed that improvements were more directed at the selection and matchmaking of traditional children play and teaching materials to be taught. There was no substantial input to the format and components of the instructional model. Thus, the traditional children play based instructional model of the validation results was presented on Table 3 . 
Table 3. Traditional children play-Based Instructional Model

\section{Traditional Children Play-Based Instructional Model \\ 1. Concept/ Theoretical Basis: \\ 1.1. Traditional Children Play-Based Instructional Model is a design or blueprint of the teaching-learning process that uses Traditional children play as medium for developing fundamental motor skill. \\ 1.2. The theories that are used as the basis for developing traditional children play-Based Instructional Model are Growth and Development Theory; the Stages of Fitts and Posner's motor learning theory (Magill, 1993); Theory of Learning Transfer; Dynamic System Theory and Growth Principles (Bahtiar, 2016); Developmentally Appropriate practice in early childhood programs (Bredekamp \& Copple, 1997); and Contructivistic Theory (Schunk, 2012); Information Acquisition Theory (Rahyubi, 2016); Bandura Social Cognitive Learning Theory (Schunk, 2012; Joyce, et. al., 2009).}

2. Sintax/Activity Step

Sintax in the learning covers following activities.

\begin{tabular}{|c|c|c|}
\hline No & Activity Step & Activity Explanation \\
\hline 1 & 2 & 3 \\
\hline 2.1 . & Opening & $\begin{array}{l}\text { Opening: } \\
\text { Morning Meeting: } \\
\text { - Sharing with children, syiar and habituation, Singing songs "Kupu Kuwi" and } \\
\text { Burung Kakatua. } \\
\text { - Explanation of today's activities } \\
\text { Question and answer: Mention the vowels and consonants of the verses sung by } \\
\text { the teacher then mimic the letters. (Кири Kuwi and Burung Kakatua) }\end{array}$ \\
\hline 2.2 . & Main Activity & $\begin{array}{l}\text { FAMILY CORNER } \\
\text { Giving assignments: Prepare planning, make bird cage or insect shape from a } \\
\text { cardboard in } 1 \text { group } \\
\text { FAMILY CORNER } \\
\text { Giving assignments: Paint brushes of birds or insects }\end{array}$ \\
\hline 2.3 . & Break & $\begin{array}{l}\text { Break Prayer \& enter bathroom } \\
\text { Playing the game "Bethet thing thong", mimicking the movements of birds and } \\
\text { insects } \\
\text { Pray exit from bathroom } \\
\text { Prayers of before and after eating and drinking }\end{array}$ \\
\hline 2.4 . & Closing & $\begin{array}{l}\text { Afternoon Meeting } \\
\text { - Conclusion of today's activities, and } \\
\text { Today's evaluation and reflection of activities } \\
\text { Closing: Closing prayer, and Greetings }\end{array}$ \\
\hline
\end{tabular}

\section{Social System}

Teacher's opening/initial activities; Teacher's main activities; and Teacher's final activity.

Preliminary/initial activities students; Student main activities; and Child's final activity.

\section{Reaction Principle}

Preliminary activity: The teacher invites children to pray and memorize short letters from Quran and hadiths. The teacher gives an example of how to repeat letters correctly. The teacher compliments the child who succeeds in mentioning vocal and consonant letters, as well as guiding children who have not been able to mention vowel letters, consonants and mimic letters.

Core activities: The teacher invites children to plan and do assigned activities. The teacher practices how to make assigned objects. The teacher gives praise to the child who can carry out the task well, the teacher also guides the child who has not been able to make the assignment. Resting activities, teachers supervise activities carried out by children, and ask children to wash their hands.

Final activity: The teacher conveys a message so that students are diligent, obedient to their parents, invite them to pray, say hello and invite hand shakes.

\section{Support System}

Conditions needed to implement the learning process: Daily Lesson Plan, Students Tasks Sheets, and other learning resources.

\section{Model Impact}

5.1. Direct influence (instructional) or planned objectives.

5.2. Indirect effects (nurturant) or accompaniment impacts caused by learning. 


\section{Discussion}

Model development has gone through three stages namely (1) identification of theoretical foundation that will be applied to use physical activity in developing basic motor skills of kindergarten students, and design determination of the instructional model to be compiled, (2) identification and assessment of traditional children play that can develop fundamental motor skill aspects of kindergarten students by considering the characteristics of the fundamental motor skills of students to be developed, as well as the values and elements of movement in traditional children play, (3) validation of instructional model by experts and practitioners. From the three stages of development that have been done, validated traditional children playbased instructional model is produced which is ready to be tested.

The instructional model that applies traditional children play as its medium is then called traditional children play-based instructional model. As the name implies, this model is designed to facilitate the development of kindergarteners' fundamental motor skills optimally, so that being able to deliver children has strong foundation to develop all potentials at next stage. Vygotsky (in Jatmikowati, Angin, \& Ernawati, 2015) states that through game activities, early childhood not only develops their social abilities, but also gets the opportunity to achieve their highest developmental abilities. This is in line with the results of the Stodden, et. al. research (2008); Lestari \& Ratnaningsih (2016) conclude that children's motor abilities must be developed optimally as early as possible and given variety of movement experiences to produce sufficient levels of movement skills to develop further and varied.

In order for kindergarten teaching learning process to provide varied learning experiences and movement experiences, teachers can take advantage of traditional play activities because kindergarten learning is very closely related to game and play. Khalid (2008); Mostafavi, et. al. (2013); Pasand, Ahmadian, Alsaadi, \& Bahramian (2014); Fatoni, Putri, \& Hartono (2015); Suherman, et. al. (2017) state that learning programs that use traditional games are effective and practical way to improve the level of physical fitness and fundamental movement skills of kindergarten students. Traditional games are useful for delivering healthy growth for early childhood that is improving fine and gross motor skills, improving control and balance, developing eye and hand coordination, increasing spatial awareness, and developing social skills. By utilizing game activities, children experience the process of learning and developing as individuals and as members of the community.

Not all traditional children plays can be used as medium forkindergarten teaching learning process. Therefore, traditional children play need to be selected and adapted to the characteristics of the learning material and learning objectives. This is in line with Pasand, et. al. (2014) shows that playing is the way children learn. However, not all traditional children plays can be used as medium and learning materials in Kindergarten, therefore, those needs to be selected and sorted according to the characteristics and instructional goals. Research results of Jaydari, Rouzbahani, \& Hasanvand (2016) added that the selection of traditional games in physical education learning must be done carefully and wisely because of the diversity oftraditional game forms and differences in the impact of the game on the development of one or all children basic movement skill elements. Accuracy and precision need to be done in the selection of children for learning because there are many benefits obtained and the use of traditional children play. In addition, Haywood \& Getchell (2005); Morrison (2012); Fitts \& Posner (in Magill, 1993) suggest that the use of traditional games in kindergarten teaching learning process considers the principles of motor development, stages of motor learning, and motor learning theory. Added by Bredekamp \& Copple (1997); Schunk (2012); Bahtiar (2016) that the learning process to develop fundamental motor skills of kindergarten students is also based on Dynamic system theory and growth principles, developmentally appropriate practice in early childhood program, Bandura Cognitive Learning Theory, and Contructivism Theory, therefore, children must have wide opportunities in the learning process to develop their full potential because the development of fundamental motor skills is a key factor for the development of all children potentials.

The advantage of using traditional children play in learning is shown by Dewantara (2008); Kovacevic \& Opic (2014); Jaydari, et. al. (2016) that the use of traditional games in learning 
develops basic mobility, encourages meticulous attitudes in works, and builds bridges between the past and present, encourages children to appreciatetheiroriginalculturalheritage, provides pedagogical impact which goes far beyond the subject matter, helps develop emovemental intelligence and the ability to fill and succeed in life. Thus, the use of traditional children play in kindergarten teaching learning process is suitable and need not be debated anymore because many benefits are obtained, besides also in accordance with the characteristics of children.

Traditional children play-based instructional model compiled based on critical study of the theory and empirical data from the results of the study and the results of observations on several teaching learning processes done in several kindergartens already have adequate scientific foundation. The format of the instructional model has complete element. However, the instructional model still needs to be validated by experts and practitioners before being tested in the field. To validate the instructional model design, Tracey (2007) suggests that internal validation done as confirmation of the components of model and the processes that take place in there in the model compiled. In addition, external validation is done to validate the impact of the results of using the model. As often occurs in the case in development research and design, internal and external validation is an integral part of the research design and model development. The validation results by experts and practitioners show that the format of traditional children play - based instructional model becomes (1) theoretical concepts/foundations, (2) teaching learning stages, (3) social systems, (4) reaction principles, (5) support systems, and (6) model impact.

\section{CONSLUSION}

Regarding the research objectives, results and discussion, the conclusions that can be put forward are as follows. The results of literature study obtained several theories that can be used for theoretical basis, such as the principles of child motor development and stages of motor learning, Transfer of learning theory, Bandura Cognitive Learning Theory, Constructivistic Theory, and Dynamic system theory and development principles. Based on the theoretical foundation, traditional children play-based Instructional Model is prepared with (1) concept/theoretical basis, (2) stages of teaching learning, (3) social systems, (4) reaction principles, (5) support systems, and (6) model impact elements.

Out of 87 Traditional children plays identified, 23 Traditional children play can be used to develop fundamental motor skills by considering traditional children paly having values and elements of movement that are in accordance with the needs for developing children's fundamental motor skills, and considering the requirements for kindergarten learning characteristics, and requirement characteristics of fundamental motor skill that will be developed.

After going through two stages, then the traditional children play-based instructional model is validated by experts and practitioners. The validation results show that the instructional model is having the following components (1) Concept/theoretical basis, (2) teaching-learning stages, (3) social systems, (4) reaction principles, (5) support systems, and (6) model impact.

\section{AKCNOWLEDGEMENT}

Thank you to the Ministry of Research, Technology and Higher Education for funding this research.

\section{REFERENCES}

Akbari, H. (2009). The effect of traditional games in fundamental motor skill development in 7 -9 year-old boys. Iran Journal of Pediatric, 19(02), 123-129.

Ariani, C, Munawaroh, S., Hartoyo, H., Wahyono, T. T., \& Maharkesti, M. (1997/1998). Pembinaan Nilai Budaya melalui Permainan Rakyat Daerah Istimewa Yogyakarta. Yogyakarta: Departemen Pendidikan dan Kebudayaan.

Bakhtiar, S. (2013). The implementation of dynamic system theory and the principles of growth in physical education of elementary school. Asian Social Science, $9(12)$, 105-109. doi:10.5539/ass. v9n12p105. 
Borg, W. R. \& Gall, M. D. (1983). Educational research: An introduction ( $4^{\text {th }}$ ed.). New York, NY: Longman.

Bredekamp, S., \& Copple, C. (1997). Developmentally appropriate practice in early childhood programs (Rev. ed.). Washington, DC: National Association for the Education of Young Children.

Brubaker, K. D. (2011). The important of physical education in today's school (Doctoral Dissertation, Asshland University). Retrieved from https://etd.ohiolink. edu/!etd.send file?accession=ashland 132 1423014\&disposition=inline.

Dewantara, K. H. (2009). Мепији manusia merdeka. Yogyakarta: Leutika.

Direktorat Pembinaan TK/SD. (2008). Pengembangan model pembelajaran di taman kanak-kanak. Jakarta: Departemen Pendidikan Nasional.

Eggen, P. \& Kauchak, D. (2012). Strategies and models for teachers: Teaching content and thinking skills $\left(6^{\text {th }}\right.$ ed.). Boston: Pearson Education, Inc..

Fatoni, F., Putri, R. I. I., \& Hartono, Y. (2015). Permainan tradisional Batok kelapa dalam membangun konsep pengukuran panjang kelas II SD. Cakrawala Pendidikan, 34(1), 97-102. doi:10.21831/cp.v1i1.4180.

Haywood, K. \& Getchell, N. (2005). Life span motor development. Champaign IL.: Human Kinetics.

Hartley, R. E., Frank, L. K., \& Goldenson, R. M. (2000). Understanding children's play. London: Routledge.

Jaydari, M., Rouzbahani, M., \& Hasanvand, R. (2016). The effect of traditional games on the development of transfer and manipulation motor skills in boys with mental retardation. International Journal of Physical Education, Sports and Health, 3(6), 134-136.
Jatmikowati, T. E., Angin, R., \& Ernawati, E. (2015). Model dan materi pendidikan seks anak usia dini perspektif gender untuk menghindarkan sexual abuse. Cakrawala Pendidikan, 34(3), 434-448. doi:10.21831/ cp.v3i3.7407.

Joyce, B., Weil, M., \& Calhoun, E. (2009). Models of teaching (model-model pembelajaran) (A. Fawaid \& A. Mirza, Trans.). Yogjakarta: Pustaka Pelajar.

Khalid, S. (2008, December). Value of traditional games. Nurture, (5), pp. 19-21.

Kovacevicì, T., \& Opicì, S. (2014). Contribution of traditional games to the quality of students' relations and frequency of students' socialization in primary education. Croatian Journal of Education, 16(Sp.Ed.1), 95-112.

Lestari, I. \& Ratnaningsih, T. (2016). The effects of modified games on the development of gross motor skill in preschoolers. International Journal of Evaluation and Research in Education (IJERE), 5(3), 216 220. doi:10.11591/ijere.v5i3.4542.

Magill, R. (1993). Motor learning: Concepts and applications. Boston: Brown \& Benchmark Pubs.

Martono, M. (2014). Pembelajaran seni lukis anak berdasarkan pengalaman lomba. Cakrawala Pendidikan, 33(1), 92-102. doi:10.21831/cp.v1i1.1865.

Metzler, M. W. (2011). Instructional models for physical education ( $3^{\text {rd }}$ ed.). Scottsdale: Taylor \& Francis, Inc.

Moeslichatoen, R. (2004). Metode pengajaran di taman kanak-kanak. Jakarta: Rineka Cipta.

Morrison, G. S. (2012). Fundamentals of early childhood education (Dasar-dasar pendidikan anak usia dini (PAUD)) (S. Romadhona \& A. Widiastuti, Trans.). Jakarta: PT. Indeks 
Mostafavi, R. M. D., Ziaee, V., M. D; Akbari, H., \& Haji-Hosseini, S. (2013). The effects of SPARK physical education program on fundamental motor skills in 4-6 year-old children. Iran Journal of Pediatric, 23(2), 216-219.

Pasand, F., Ahmadian, M., Alsaadi, M. J., \& Bahramian, M. (2014). Impact of tradisional exercises on perceptual-motor development in elementary school girl students. Indian Journal of Fundamental and Applied Life Sciences, 4(S3), 12971302.

Saskatchewan Education. (2009). Children first: A curriculum guide for Kindergarten. Retrieved from: http://www.sasked.gov. sk.ca/docs/kindergarten/kindacti.html.

Schunk, D. H. (2012). Learning theories: An educational perspective. $6^{\text {th }}$ ed. Boston: Pearson Education, Inc.
Stodden, D. F., Goodway, J. D., Langendorfer, S. J., Roberton, M. A., Rudisill, M. E., Garcia, C., \& Garcia, L. E. (2008). A developmental perspective on the role of motor skill competence in physical activity: An emergent relationship. Quest, 60(2), 290-306. doi:10.1080/00336297.20 08.10483582 .

Suherman, W. S., Nopembri, S., \& Muktiani, N. R. (2017). Pengembangan Majeda berbasis dolanan anak untuk mengoptimalkan tumbuhkembang siswa Taman kanakkanak. Cakrawala Pendidikan, 36(2), 220-232. doi:10.21831/cp.v36i2.13542

Sujiono, B. (2009). Konsep dasar pendidikan anak usia dini. Jakarta: PT. Indeks.

Tracey, M. W. (2007). Design and development research: A model validation case. Educational Technology Research and Development, 57(4), 553-571. doi:10.1007/s11423-007-9075-0.

Willis, J. E., \& Hymon-Parker, S. (2010). Expanding multicultural activities across the curriculum for preschool. Retrieved from http://www.kon.org/urc/v5/willis. html. 